\title{
A prospective investigation of injury incidence and injury risk factors among army recruits in military police training
}

\author{
Joseph J Knapik*, Bria Graham¹, Jacketta Cobbs², Diane Thompson ${ }^{3}$, Ryan Steelman ${ }^{1}$ and Bruce H Jones ${ }^{1}$
}

\begin{abstract}
Background: United States Army military police (MP) training is a 19-week course designed to introduce new recruits to basic soldiering skills, Army values and lifestyle, and law enforcement skills and knowledge. The present investigation examined injury rates and injury risk factors in MP training.

Methods: At the start of training, 1,838 male and 553 female MP recruits were administered a questionnaire containing items on date of birth, height, weight, tobacco use, prior physical activity, injury history, and menstrual history. Injuries during training were obtained from electronic medical records and the training units provided data on student graduation and attrition.

Results: Successfully graduating from the course were $94.3 \%$ of the men and $83.7 \%$ of the women. Experiencing at least one injury during training were $34.2 \%$ of the men and $66.7 \%$ of the women (risk ratio (women/men) $=1.95$, $95 \%$ confidence interval $=1.79-2.13$ ). Recruits were at higher injury risk if they reported that they were older, had smoked in the past, or had performed less frequent exercise or sports prior to MP training. Men were at higher injury risk if they reported a prior injury and women were at higher risk if they reported missing at least six menstrual cycles in the last year or had previously been pregnant.
\end{abstract}

Conclusion: The present investigation was the first to identify injury rates and identify specific factors increasing injury risk during MP training.

Keywords: Age, Smoking, Exercise, Physical activity, Prior injury, Menstrual cycle, Pregnancy

\section{Background}

United States (US) Army Basic Combat Training is a 10week course designed to develop basic soldiering skills and introduce a new Army recruit into Army values and lifestyle. Most US soldiers complete basic training first and then move on to Advanced Individual Training where they learn their military occupational specialty with a new group of soldiers at another location. However, some military occupational specialties require soldiers to train as a cohort and move directly from basic training into their occupational specialty training with the same group of soldiers and some overlap between Basic Combat Training and occupational specialty

\footnotetext{
*Correspondence: joseph.knapik@us.army.mil

'US Army Institute of Public Health, Portfolio of Epidemiology and Disease Surveillance, ATTN: MCHB-IP-DI, 1570 Stark Road, Aberdeen Proving Ground, MD 21010, USA

Full list of author information is available at the end of the article
}

training. This is called One-Station Unit Training (OSUT). One type of OSUT is the 19-week course conducted for the military police (MP). Like basic training, the first 10 weeks are devoted to the development of basic soldiering skills in which the recruit is very physically active. There is almost daily physical training in the morning in addition to marksmanship training, periodic road marches, confidence/obstacle course negotiation, high tower operations, team and individual movement exercises, land navigation, and other physical activities. The latter weeks are devoted to training more specific to the occupational specialty including unarmed selfdefense and suspect apprehension, civil disturbance training, law and order operations, special weapons instruction, area security exercises, intelligence operations, enemy prisoner of war/civilian internee exercises, use and set-up of tactical control points, convoy and patrol 
operations, search and seizure operations, and use of levels of force.

Recruits in basic training and OSUT perform a large volume of physical training and physical activity and because of this they are at risk of injury [1]. A number of previous studies have examined injury rates in basic training [2-5] and these investigations indicate that recruits have one of the highest injury rates of any group in the military [6]. Only one previous investigation has examined OSUT training and that was in infantry training that involved no women [7]. The purpose of the present study was to examine injury rates and injury risk factors among male and female recruits in MP OSUT.

\section{Methods}

Participants were 1,838 male and 553 female recruits in MP OSUT at Fort Leonard Wood, Missouri. These recruits were from 14 separate training companies in two battalions that began training between 4 May 2010 and 25 February 2011 and completed training between 16 September 2010 and 7 July 2011. None of the MP OSUT companies involved in "Exodus" were included. Exodus was a two-week period over the late December and early January period when no training was conducted and the recruits were allowed to return to their homes. The study protocol was reviewed and approved by the Human Subjects Protection Office at the US Army Institute of Public Health as a public health practice project.

\section{Procedures}

Recruits completed a lifestyle questionnaire within the first week of training. This questionnaire contained items on date of birth, height, weight, tobacco use, prior physical activity, injury history, and menstrual history.

Injury data were obtained from the Defense Medical Surveillance System of the Armed Forces Health Surveillance Center (AFHSC). The AFHSC regularly compiles data on ambulatory (outpatient) encounters occurring within military treatment facilities, as well as those occurring outside these facilities (civilian care) and paid for by the US Department of Defense. A list of recruits from the units being evaluated and the dates of their training cycles were provided to the AFHSC. The AFHSC returned visit dates and International Classification of Diseases, Revision 9, Clinical Modification (ICD-9) codes for all outpatient medical visits during the training cycle timeframe. Five injury indices were calculated from the data provided by the AFHSC. These indices were the Installation Injury Index, the Modified Installation Injury Index, the Training-Related Injury Index, the Comprehensive Injury Index (CII), and the Overuse Injury Index. These indices included specific ICD-9 codes, as described previously [8]. The Installation Injury Index and Training-Related Injury Index were developed by personnel at the AFHSC. The Installation Injury Index has been used to compare overall injury rates (acute and overuse) among military posts and is reported on a monthly basis at the AFHSC website (http://afhsc.army. mil). The Training-Related Injury Index is limited to lower extremity overuse injuries and has been used to compare injury rates among Army Basic Combat Training locations. The Modified Installation Injury Index, CII, and Overuse Injury Index were developed by personnel in the Injury Prevention Program at the Army Institute of Public Health. The Modified Installation Injury Index captures a greater number of injuries than the Installation Injury Index, including more overusetype injuries. The CII captures all ICD-9 codes related to injuries defined as physical damage to the body as a result of an energy exchange [9]. The Overuse Injury Index captures the subset of musculoskeletal injuries presumably resulting from cumulative microtrauma (overuse injuries) such as stress fractures, stress reactions, tendonitis, bursitis, fasciitis, arthralgia, neuropathy, radiculopathy, shin splints, synovitis, sprains, strains, and musculoskeletal pain (not otherwise specified). The CII was the primary outcome measure in this report.

Recruits that attrited from training, as well as the date and reason were provided by the training companies. These data were verified from information in the Directorate of Human Resources, Trainee Student Processing Branch at Fort Leonard Wood and from the Resident Individual Training Management System. Attrition could have been due to discharge from service or recycling. Discharges were recruits who were not suitable for service in the Army and were formally released from their service commitment. A discharge may have been due to a medical condition that existed prior to service or developed during training, or for a non-medical reason. Non-medical discharges were generally due to the inability of the recruit to adapt to the military environment because of lack of ability (could not adequately perform critical military tasks) or for psychosocial reasons (lack of motivation, inability to follow orders, personality problems, commission of serious offenses). A recycle was a recruit who needed additional training to complete training requirements and was sent to another unit to complete this training. Recycles were not followed once they left their initial training unit.

\section{Data analysis}

Age was calculated from the date of birth to the date of the start of training. Body mass index (BMI) was calculated as weight/height ${ }^{2}$ obtained from the questionnaire [10]. Cumulative injury incidence was calculated as the number of recruits with $\geq 1$ injury/the total number of 
recruits $X 100 \%$. Injury incidence rate was calculated as number of recruits with $\geq 1$ injury/the total number of recruits $\mathrm{X}$ number of days in training (injuries/1,000 person-days). The Open Epidemiological Calculator [11] was used to obtain comparisons (risk ratios, rate ratios and $95 \%$ confidence intervals $(95 \% \mathrm{CI})$ ) between men and women on attrition and injury variables.

Other analyses were performed using the Statistical Package for the Social Sciences (SPSS), Version 18.0. Cox regression (survival analysis) was used to examine the association between the time to the first CII injury and other potential injury risk factors from the questionnaire. Once a recruit had an injury, his or her contribution to time in training was terminated (censored). Those who attrited from training had their time censored at the day they left training, unless their time had already been censored as the result of an injury. All potential risk factors were entered into the regression models as categorical variables. Continuous variables were converted to categorical variables based on recommendations from the literature or findings from previous basic training investigations [5,6,12]. Age was separated into 3 groups $(<20.0,20.0-24.9, \geq 25.0$ years $)$. BMI was separated into 3 groups $\left(<25.0,25.0-29.9\right.$ and $\left.\geq 30 \mathrm{~kg} / \mathrm{m}^{2}\right)$ as recommended by the National Institute of Health [13]. Physical activity questions were categorized based on recommended activity levels specified by the American College of Sports Medicine [14]. For all Cox regressions, simple contrasts were used, comparing the injury hazard at a baseline stratum of a variable (defined with a hazard ratio (HR) of 1.00) with other strata of the same variable. Variables were included in a multivariate backward stepping Cox regression if they achieved $\mathrm{p}<0.10$ in the univariate analyses [15]. Multivariate Cox regressions established the association between a variable and injury risk with other significant injury risk factors included. Multivariate Cox regression requires complete data on all included cases so that any cases with without complete data are eliminated from the analysis.

\section{Results}

The mean \pm standard deviation age, height, weight, and BMI of the male recruits was $20.6 \pm 3.0$ years, $178 \pm 7$ $\mathrm{cm}, 78 \pm 12 \mathrm{~kg}$, and $24.6 \pm 3.3 \mathrm{~kg} / \mathrm{m}^{2}$, respectively. Among female recruits, these values were $20.5 \pm 2.8$ years, $164 \pm 7 \mathrm{~cm}, 63 \pm 8 \mathrm{~kg}$, and $23.5 \pm 2.6 \mathrm{~kg} / \mathrm{m}^{2}$, respectively.

Table 1 shows the number and proportion of recruits who graduated and attrited from training. Compared to those who graduated, women were 3.13 (95\%CI $=2.31$ 4.23) times more likely to be discharged (all causes) than men, and $2.75(95 \% \mathrm{CI}=1.42-5.33)$ times more likely to be recycled than men.
Table 1 Graduation and Attrition in MP training

\begin{tabular}{lccccc}
\hline Final status & \multicolumn{2}{c}{ Men } & & \multicolumn{2}{c}{ Women } \\
\cline { 2 - 3 } \cline { 6 - 6 } & N & Proportion (\%) & & N & Proportion (\%) \\
\hline Graduated & 1734 & 94.3 & & 463 & 83.7 \\
Medical Discharge & 26 & 1.4 & & 40 & 7.2 \\
Other Discharge & 53 & 2.9 & & 33 & 6.0 \\
Recycle & 20 & 1.1 & & 15 & 2.7 \\
AWOL $^{a}$ & 1 & 0.1 & & 0 & 0.0 \\
Unknown & 4 & 0.2 & & 2 & 0.4 \\
\hline
\end{tabular}

${ }^{\mathrm{a} A W O L}=$ absent without leave.

Table 2 shows the injury incidence and injury incidence rates for each of the injury indices and compares the men and women. Women were more likely to be injured than men and the two overuse injury indices (Overuse Injury Index and Training-Related Injury Index) showed larger gender differences than the other injury indices. The total amount of time in training for all recruits was 241,878 days for the men and 71,630 days for the women.

Table 3 displays the association between CII injury risk and the variables under investigation. Not all recruits answered all questions so the sample sizes for each variable are shown. For both men and women, higher injury risk was associated with older age, having smoked $\geq 100$ cigarettes in the past, less frequent exercise or sports activity, a shorter period of running/jogging prior to OSUT, and a shorter period of weight training prior to OSUT. For men, injury risk was also associated with a younger age for the onset of smoking, more days of smoking, more cigarettes per day, a self-rating of less physical activity prior to OSUT, and a prior injury, especially if that prior injury restricted training for a week or more or the recruit had not totally recovered from the injury. Among the women, risk was generally elevated at similar strata of these variables but the magnitudes of the risks were much smaller than that for the men. Among the women, injury risk was also associated with having gone $\geq 6$ months without a menstrual cycle in the last year and having been pregnant.

Table 4 shows the result of the multivariate Cox regression. Complete data for the multivariate analysis was available on 1831 of the 1838 men (99.6\%) and 542 of the 553 women (97.5\%). Among the men, independent injury risk factors included older age, having smoked $\geq 100$ cigarettes in the past, a lower physical activity selfrating, and reporting not having recovered from a previous injury. Among the women, independent injury risk factors included older age, having smoked $\geq 100$ cigarettes in the past, a shorter time running/jogging before OSUT, and having gone $\geq 6$ months without a menstrual cycle in the last year. 
Table 2 Male and Female injury incidence and injury Incidence rates in MP training

\begin{tabular}{|c|c|c|c|c|c|c|}
\hline \multirow[t]{2}{*}{ Injury Index } & \multicolumn{2}{|c|}{ Injury incidence (\%) } & \multirow{2}{*}{$\begin{array}{c}\text { Risk ratio - } \\
\text { Women/Men } \\
(95 \% \mathrm{Cl})\end{array}$} & \multicolumn{2}{|c|}{ Injury incidence rate (injuries/1,000 person-days) } & \multirow{2}{*}{$\begin{array}{c}\text { Rate ratio - } \\
\text { Women/Men } \\
(95 \% \mathrm{Cl})\end{array}$} \\
\hline & Men & Women & & Men & Women & \\
\hline Installation Injury Index & 30.3 & 62.7 & $2.07(1.88-2.28)$ & 2.30 & 4.84 & $2.10(1.84-2.41)$ \\
\hline Modified Installation Injury Index & 33.4 & 66.4 & $1.99(1.82-2.17)$ & 2.53 & 5.12 & $2.02(1.78-2.30)$ \\
\hline Overuse Injury Index & 23.6 & 58.4 & $2.47(2.22-2.76)$ & 1.79 & 4.51 & $2.51(2.18-2.90)$ \\
\hline Training-Related Injury Index & 17.8 & 51.2 & $2.88(2.53-3.27)$ & 1.35 & 3.96 & $2.92(2.49-3.43)$ \\
\hline Comprehensive Injury Index & 34.2 & 66.7 & $1.95(1.79-2.13)$ & 2.60 & 5.17 & $1.99(1.75-2.26)$ \\
\hline
\end{tabular}

\section{Discussion}

The present investigation was the first to indentify the injury risk and injury risk factors in MP training, and only the second [7] to explore these issues in any type of OSUT training. In past studies of Basic Combat Training, injury incidences have ranged between $14 \%$ to $42 \%$ for men and $41 \%$ to $67 \%$ for women [6] while the study of infantry OSUT found that the injury incidence among the men was $46 \%$ [7]. This compares with the incidence of $34 \%$ and $67 \%$ of men and women, respectively, in the present study (CII). Comparisons between injury incidence in this investigation and that of past studies are most appropriately performed using the CII. This index has been used in many recent Basic Combat Training investigations [5,16,17] and is similar to that used in older studies that involved screening of hardcopy medical records [2-4]. The injury incidences in the present investigation are within the ranges of that previously seen for Basic Combat training, albeit on the higher end of the previous studies, but lower than that of infantry OSUT. The early part of MP OSUT was essentially identical to Basic Combat Training and a similar injury rate might be expected in this period. MP training continued for an additional 9 weeks and this additional period increased the time at risk.

In addition to injury incidence, the present investigation also identified a number of factors that put recruits at higher injury risk. Older age was an independent injury risk factor among both men and women and this is in consonance with other studies in Basic Combat Training $[3,5,7,18,19]$ as well as other military and civilian investigations where participants performed similar levels of physical activity [20,21]. The reason for the higher susceptibility to injury in older recruits may have to do with age-related changes in stem cells, declines in fitness, and/or prior injury history. The ability of resident stem cells to initiate and conduct tissue repair declines with age [22] and this could make older individuals more susceptible to overuse-type injuries in which small microtraumas accumulate over time and repair in the older tissue does not keep pace with these repeated microtraumas. It is also possible that repetitive microtraumas, coupled with slower regenerative processes, may also weaken muscle and connective tissues to the point where sudden energy exchanges are more likely to cause acute (traumatic) tissue damage. With regard to fitness, aging results in a loss of muscle mass, muscle strength, muscular endurance, aerobic capacity, and flexibility [23,24]. The loss of aerobic capacity and muscular endurance can begin as early as age 25 [24]. These age-related changes reduce absolute fitness levels and may make injuries more likely since lower fitness has been consistently related to injury [2-4,18,25-31]. With regard to prior injuries, it is possible that older recruits may be more likely to have experienced lower limb injuries in the past that make them more susceptible to injuries in MP training. Prior injuries have been shown to be a risk factor for new injuries in many previous studies [29,32-42]. To examine this hypothesis in the present investigation, self-reported prior injuries were stratified by age. Table 5 shows that in the two younger age groups there was little difference in injury incidence during MP training between those with and without prior lower limb injuries. In the oldest age group, there was a weak trend such that those with prior lower limb injuries had a somewhat higher injury incidence during MP training. Thus, the hypothesis that prior injury may make older recruits more susceptible to injuries in training was only weakly supported here.

Beside older age, the present investigation found that recruits who reported cigarette smoking in the past were at higher injury risk. Among the men, those who had started smoking earlier in life or had smoked in the 30 days before Basic Combat Training were also at elevated injury risk and a dose-response was generally evident (i.e., progressively more smoking associated with progressively higher injury risk). Women showed a similar trend with regard to early smoking or recent smoking but the association was weaker than that among the men. Interestingly, $87 \%$ of men and $88 \%$ of women who reported that they had smoked 100 cigarettes in their lives had also smoked in the 30 days before training. If those who had smoked in the 30 days before training were included in the multivariate analysis in place of those who had smoked 100 cigarettes in their lives, the HRs for the other variables changed little and those 
Table 3 Univariate associations between questionnaire variables and injury risk among MP recruits

\begin{tabular}{|c|c|c|c|c|c|c|c|}
\hline \multirow[t]{2}{*}{ Variable } & \multirow[t]{2}{*}{ Strata } & \multicolumn{3}{|c|}{ Men } & \multicolumn{3}{|c|}{ Women } \\
\hline & & $\mathbf{N}$ & $\begin{array}{c}\text { Hazard ratio } \\
(95 \% \mathrm{Cl})\end{array}$ & p-value & $\mathbf{N}$ & $\begin{array}{c}\text { Hazard ratio } \\
(95 \% \mathrm{Cl})\end{array}$ & p-value \\
\hline \multirow[t]{4}{*}{ Age } & $<20.0$ years & 1080 & 1.00 & Referent & 325 & 1.00 & Referent \\
\hline & 20.0-24.9 years & 623 & $1.21(1.04-1.46)$ & 0.01 & 195 & $1.25(1.00-1.55)$ & 0.05 \\
\hline & 25.0-29.9 years & 90 & $1.25(0.87-1.78)$ & 0.23 & 23 & $1.21(0.72-2.05)$ & 0.47 \\
\hline & $\geq 30.0$ years & 38 & $2.17(1.41-3.33)$ & $<0.01$ & 10 & $2.99(1.47-6.07)$ & $<0.01$ \\
\hline \multirow[t]{3}{*}{ Body Mass Index } & $<25.0 \mathrm{~kg} / \mathrm{m}^{2}$ & 1048 & 1.00 & Referent & 401 & 1.00 & Referent \\
\hline & $25.0-29.9 \mathrm{~kg} / \mathrm{m}^{2}$ & 658 & $1.13(0.96-1.33)$ & 0.15 & 145 & $0.91(0.72-1.15)$ & 0.42 \\
\hline & $\geq 30 \mathrm{~kg} / \mathrm{m}^{2}$ & 132 & $1.05(0.77-1.43)$ & 0.77 & 5 & $0.96(0.31-3.01)$ & 0.95 \\
\hline \multirow[t]{2}{*}{ Smoked $\geq 100$ Cigarettes in Life } & No & 1273 & 1.00 & Referent & 404 & 1.00 & Referent \\
\hline & Yes & 563 & $1.37(1.17-1.61)$ & $<0.01$ & 149 & $1.28(1.00-1.60)$ & 0.05 \\
\hline \multirow[t]{4}{*}{ Age Started Smoking } & Never & 932 & 1.00 & Referent & 316 & 1.00 & Referent \\
\hline & $<13$ years & 72 & $1.54(1.07-2.23)$ & 0.02 & 19 & $1.37(0.78-2.40)$ & 0.27 \\
\hline & $13-16$ years & 520 & $1.18(0.99-1.42)$ & 0.07 & 134 & $1.05(0.82-1.34)$ & 0.72 \\
\hline & $\geq 17$ years & 314 & $1.05(0.83-1.31)$ & 0.69 & 84 & $1.09(0.81-1.46)$ & 0.57 \\
\hline \multirow[t]{4}{*}{ Days Smoked in 30 Days Before OSUT } & None & 1368 & 1.00 & Referent & 425 & 1.00 & Referent \\
\hline & 1-9 days & 107 & $1.09(0.77-1.53)$ & 0.63 & 28 & $1.25(0.79-1.96)$ & 0.34 \\
\hline & 10-19 days & 74 & $1.13(0.76-1.66)$ & 0.55 & 15 & $0.85(0.44-1.66)$ & 0.64 \\
\hline & $\geq 20$ days & 298 & $1.45(1.19-1.77)$ & $<0.01$ & 85 & $1.20(0.91-1.58)$ & 0.20 \\
\hline \multirow[t]{4}{*}{ Cigarettes Smoked in 30 Days Before OSUT } & None & 1375 & 1.00 & Referent & 425 & 1.00 & Referent \\
\hline & 1-9 cigarettes/day & 270 & $1.29(1.04-1.59)$ & 0.02 & 80 & $1.11(0.84-1.48)$ & 0.46 \\
\hline & 10-19 cigarettes/day & 126 & $1.23(0.91-1.67)$ & 0.17 & 31 & $1.12(0.71-1.77)$ & 0.61 \\
\hline & $\geq 20$ cigarettes/day & 66 & $1.76(1.23-2.52)$ & $<0.01$ & 17 & $1.51(0.88-2.59)$ & 0.13 \\
\hline \multirow[t]{2}{*}{ Used Smokeless Tobacco 30 Days Before OSUT } & No & 1473 & 1.00 & Referent & 536 & 1.00 & Referent \\
\hline & Yes & 365 & $1.00(0.82-1.21)$ & 0.96 & 17 & $0.80(0.44-1.45)$ & 0.46 \\
\hline \multirow[t]{5}{*}{ Physical Activity Before OSUT Compared to Peers } & Much less active & 91 & $1.52(1.06-2.17)$ & 0.02 & 62 & $1.25(0.81-1.93)$ & 0.32 \\
\hline & Less active & 315 & $1.53(1.20-1.96)$ & $<0.01$ & 128 & $1.14(0.78-1.67)$ & 0.49 \\
\hline & Average & 441 & $1.08(0.85-1.38)$ & 0.53 & 146 & $0.90(0.62-1.31)$ & 0.58 \\
\hline & More active & 637 & $0.85(0.67-1.08)$ & 0.18 & 161 & $0.84(0.57-1.22)$ & 0.35 \\
\hline & Much more active & 354 & 1.00 & Referent & 56 & 1.00 & Referent \\
\hline \multirow[t]{3}{*}{ Exercise or Sports Frequency 2 Months Before OSUT } & $\leq 1$ time/week & 281 & $1.42(1.12-1.80)$ & $<0.01$ & 90 & $1.39(1.02-1.91)$ & 0.04 \\
\hline & 2-4 time/week & 912 & $0.97(0.82-1.15)$ & 0.70 & 310 & $1.13(0.88-1.44)$ & 0.34 \\
\hline & $\geq 5$ time/week & 707 & 1.00 & Referent & 153 & 1.00 & Referent \\
\hline \multirow[t]{3}{*}{ Time Running/Jogging before OSUT } & $\leq 1$ month & 451 & $1.38(1.08-1.68)$ & $<0.01$ & 143 & $1.66(1.18-2.32)$ & $<0.01$ \\
\hline & 2-6 months & 949 & $1.06(0.87-1.30)$ & 0.09 & 308 & $1.63(1.20-2.21)$ & $<0.01$ \\
\hline & $\geq 7$ months & 437 & 1.00 & Referent & 102 & 1.00 & Referent \\
\hline \multirow[t]{3}{*}{ Time Weight Training before OSUT } & $\leq 1$ month & 660 & $1.25(1.04-1.51)$ & $<0.01$ & 274 & $1.47(1.08-2.01)$ & 0.02 \\
\hline & 2-6 months & 537 & $1.12(0.91-1.36)$ & 0.11 & 190 & $1.33(0.95-1.86)$ & 0.09 \\
\hline & $\geq 7$ months & 640 & 1.00 & Referent & 88 & 1.00 & Referent \\
\hline \multirow[t]{2}{*}{ Prior Lower Limb Injury } & No & 1327 & 1.00 & Referent & 406 & 1.00 & Referent \\
\hline & Yes & 510 & $1.19(1.01-1.41)$ & 0.04 & 147 & $1.08(0.85-1.35)$ & 0.54 \\
\hline \multirow[t]{3}{*}{ Prior Injury Prevent Activities $\geq 1$ Week } & No prior injury & 1327 & 1.00 & Referent & 406 & 1.00 & Referent \\
\hline & No & 171 & $1.12(0.92-1.38)$ & 0.26 & 45 & $1.07(0.72-1.58)$ & 0.38 \\
\hline & Yes & 337 & $1.29(1.00-1.67)$ & 0.05 & 102 & $1.22(0.79-1.88)$ & 0.75 \\
\hline
\end{tabular}


Table 3 Univariate associations between questionnaire variables and injury risk among MP recruits (Continued)

\begin{tabular}{|c|c|c|c|c|c|c|c|}
\hline \multirow[t]{3}{*}{ Totally Recovered from Prior Injury } & No prior injury & 1325 & 1.00 & Referent & 406 & 1.00 & Referent \\
\hline & No & 27 & $2.07(1.22-3.52)$ & $<0.01$ & 11 & $1.50(0.77-2.92)$ & 0.23 \\
\hline & Yes & 481 & $1.15(0.97-1.37)$ & 0.11 & 136 & $1.05(0.82-1.33)$ & 0.71 \\
\hline \multirow[t]{4}{*}{ Age at Menarche } & No menses yet & & & & 4 & $0.23(0.03-1.67)$ & 0.15 \\
\hline & $6-10$ years & & & & 48 & $1.21(0.85-1.72)$ & 0.29 \\
\hline & 11-14 years & & & & 437 & 1.00 & Referent \\
\hline & $15-17$ years & & & & 64 & $0.78(0.56-1.10)$ & 0.16 \\
\hline \multirow[t]{3}{*}{ Gone $\geq 6$ Months without Menstrual Cycle in Last Year } & No & & & & 494 & 1.00 & Referent \\
\hline & Yes & & & & 44 & $1.60(1.13-2.26)$ & $<0.01$ \\
\hline & No menses yet & & & & 4 & $0.25(0.04-1.76)$ & 0.16 \\
\hline \multirow[t]{2}{*}{ Taken Birth Control Pills in Last 12 Months } & No & & & & 299 & 1.00 & Referent \\
\hline & Yes & & & & 249 & $1.11(0.90-1.36)$ & 0.33 \\
\hline \multirow[t]{2}{*}{ Ever Pregnant } & No & & & & 494 & 1.00 & Referent \\
\hline & Yes & & & & 59 & $1.41(1.02-1.94)$ & 0.04 \\
\hline
\end{tabular}

smoking in the 30 days before training were still at higher risk (Men: HR (smokers/nonsmokers) $=1.28,95 \%$ $\mathrm{CI}=1.07-1.51 ;$ women : $\mathrm{HR} \quad$ (smokers/nonsmokers) $=$ $1.21,95 \% \mathrm{CI}=0.96-1.58)$.

Cigarette smoking prior to basic training has consistently been associated with increased injury risk in US Army and Air Force basic training [3,7,31,43-45] and in the basic training of other countries $[18,46]$. Further, smoking was associated with injury in infantry soldiers [47] and in other occupational groups [48-50]. Past basic training studies $[3,7,18,31,43,44]$ have also demonstrated a dose-response.

The association between smoking and injuries has biological plausibility, both from a physiological and psychosocial perspective. There is considerable literature showing that cigarette smoking impairs wound [51-58] and bone [59-63] healing, reduces tissue strength [64-69], and affects immune function. The immune system is important for tissue healing, since macrophages, leukocytes, and lymphocytes regulate various steps in the process and remove or assist in removal of damaged tissue [70-73], such as might be produced by microtrauma. The macrophages of smokers have lower phagocytic activity, lower responsiveness to bacterial challenge, and reduced gene expression of the proinflammatory cytokines, which are important for tissue healing [74-76]. Recruits cease smoking once they enter training but the effects of cigarette smoking on immune function is apparent beyond the length of MP OSUT training [77-83]. Besides physiological mechanisms, psychosocial factors can also be considered. Prior studies show that Air Force recruits [84] and civilians [85-87] who were cigarette smokers had higher scores than nonsmokers on various measures of risk taking. Heavy smoking ( $\geq 20$ cigarettes/day) was much more likely to be associated with multiple risk behaviors [87]. It is possible that the higher risk-taking behavior of smokers manifests itself in the activities of basic training and results in a higher injury rate among smokers.

A lower frequency of recent physical activity (exercise or sports) or a shorter history of running or weight training activity was associated with higher injury risk among both men and women. The present data are in consonance with previous studies of military basic training that found increased risk of injury among those who self-reported less physical activity $[2,3,6,7,28,88]$. In MP training, recruits perform weight-bearing physical activity primarily in the form of standing in formation, walking, and running. It seems reasonable that a higher frequency of weight-bearing physical training prior to training would result in less susceptibility to injury because of the favorable influences of physical activity on the body. Physical activity of the proper intensity, frequency, and duration can increase aerobic fitness, muscle strength, connective tissue strength, and bone health $[89,90]$. These and other factors may assist in reducing the susceptibility to injury among recruits who were physically active prior to MP training [91].

Men who reported a prior lower limb injury were at higher injury risk. This relationship appeared to be "graded", depending on the reported severity of the previous injury. That is, recruits reporting at least a weeklong limitation of the previous injury were at higher risk in MP training than those who had previous injury but did not report a week-long limitation; those who reported that they had not totally recovered from the previous injury where at much higher risk than those with a prior injury who had recovered. Among the women, the same trends were present but the associations were much weaker, likely because of the smaller 
Table 4 Multivariate association between questionnaire variables and injury risk among MP recruits

\begin{tabular}{|c|c|c|c|c|}
\hline Variable & Strata & $\mathbf{N}$ & Hazard ratio $(95 \% \mathrm{Cl})$ & p-value \\
\hline \multicolumn{5}{|l|}{ Men } \\
\hline \multirow[t]{4}{*}{ Age } & $<20.0$ years & 1080 & 1.00 & Referent \\
\hline & 20.0-24.9 years & 623 & $1.21(1.02-1.43)$ & 0.03 \\
\hline & $25-29.9$ years & 90 & $1.17(0.81-1.67)$ & 0.40 \\
\hline & $\geq 30$ years & 38 & $2.29(1.49-3.53)$ & $<0.01$ \\
\hline \multirow[t]{2}{*}{ Smoked $\geq 100$ Cigarettes in Life } & No & 1271 & 1.00 & Referent \\
\hline & Yes & 560 & $1.32(1.12-1.56)$ & $<0.01$ \\
\hline \multirow[t]{5}{*}{ Physical Activity Before Basic Training Compared to Peers } & Much Less Active & 90 & $1.46(1.01-2.10)$ & 0.05 \\
\hline & Less Active & 313 & $1.51(1.18-1.94)$ & $<0.01$ \\
\hline & Average & 439 & $1.09(0.85-1.40)$ & 0.49 \\
\hline & More Active & 637 & $0.84(0.67-1.07)$ & 0.16 \\
\hline & Much More Active & 352 & 1.00 & Referent \\
\hline \multirow[t]{3}{*}{ Totally Recovered from Prior Injury } & No Prior Injury & 1324 & 1.00 & Referent \\
\hline & No & 27 & $1.97(1.16-3.37)$ & 0.01 \\
\hline & Yes & 480 & $1.18(0.99-1.41)$ & 0.07 \\
\hline \multicolumn{5}{|l|}{ Women } \\
\hline \multirow[t]{4}{*}{ Age } & $<20.0$ years & 319 & 1.00 & Referent \\
\hline & 20.0-24.9 years & 194 & $1.25(1.00-1.55)$ & 0.05 \\
\hline & $25-29.9$ years & 20 & $1.36(0.77-2.39)$ & 0.29 \\
\hline & $\geq 30$ years & 9 & $2.56(1.19-5.49)$ & 0.02 \\
\hline \multirow[t]{2}{*}{ Smoked $\geq 100$ Cigarettes in Life } & No & 396 & 1.00 & Referent \\
\hline & Yes & 146 & $1.20(0.95-1.51)$ & 0.10 \\
\hline \multirow[t]{3}{*}{ Time Running/Jogging before Basic Training } & $\leq 1$ month & 142 & $1.61(1.14-2.26)$ & $<0.01$ \\
\hline & $2-6$ months & 300 & $1.61(1.18-2.20)$ & $<0.01$ \\
\hline & $\leq 7$ months & 100 & 1.00 & Referent \\
\hline \multirow[t]{3}{*}{ Gone $\geq 6$ Months without Menstrual Cycle in Last Year } & No & 494 & 1.00 & Referent \\
\hline & Yes & 44 & $1.66(1.17-2.36)$ & $<0.01$ \\
\hline & No Cycles Yet & 4 & $0.27(0.04-1.92)$ & 0.19 \\
\hline
\end{tabular}

Table 5 Injuries in MP training stratified by prior lower limb injury and age

\begin{tabular}{|c|c|c|c|c|c|c|}
\hline Gender & Age & Response category & $\mathrm{N}$ & Injured in training (\%) & Risk ratio $(95 \% \mathrm{Cl})$ & p-value ${ }^{a}$ \\
\hline \multirow[t]{6}{*}{ Men } & $<20.0$ Year Olds & No Prior Injury & 779 & 30.2 & $1.16(0.96-1.40)$ & 0.13 \\
\hline & & Prior Injury & 306 & 35.0 & & \\
\hline & 20.0-24.9 Year Olds & No Prior Injury & 462 & 36.8 & $1.02(0.81-1.29)$ & 0.85 \\
\hline & & Prior Injury & 162 & 37.5 & & \\
\hline & $\geq 25.0$ Year Olds & No Prior Injury & 86 & 39.5 & $1.26(0.85-1.89)$ & 0.26 \\
\hline & & Prior Injury & 42 & 50.0 & & \\
\hline \multirow[t]{6}{*}{ Women } & $<20.0$ Year Olds & No Prior Injury & 236 & 62.7 & $1.04(0.87-1.25)$ & 0.68 \\
\hline & & Prior Injury & 89 & 65.2 & & \\
\hline & 20.0-24.9 Year Olds & No Prior Injury & 145 & 69.0 & $1.02(0.82-1.25)$ & 0.89 \\
\hline & & Prior Injury & 50 & 70.0 & & \\
\hline & $\geq 25.0$ Year Olds & No Prior Injury & 25 & 64.0 & $1.37(0.92-2.03)$ & 0.21 \\
\hline & & Prior Injury & 8 & 87.5 & & \\
\hline
\end{tabular}


sample size. Other studies of basic training have not demonstrated a consistent relationship between prior injuries and injuries in training [5-7,92], although this relationship has often been demonstrated in athletes [35-38,40-42,93]. Some authors have speculated that contractile or connective scar tissues may alter movement mechanics, or that muscle tissue atrophy induced by some injuries might reduce strength or result in muscle imbalances that could affect injuries [94,95]. Many injuries may be chronic or recurrent, accounting for at least a part of this relationship.

Women who reported missing $\geq 6$ or more menstrual periods in the last year were at higher injury risk and this was an independent injury risk factor in the multivariate Cox regression. In past basic training studies, menstrual irregularities have also been shown to increase injury risk $[29,43,96]$. Investigations of female athletes have also indicated that those with menstrual irregularities have a higher injury incidence of musculoskeletal injuries [97], especially with bone stress injuries [97-99], and that these athletes take longer to recover from their injuries [100]. It has been hypothesized that amenorrhea results in hormonal changes, especially lower estrogen levels, which leads to a reduction in bone mineral density and increasing likelihood of fracture [97,99-101]. Bennell et al. [102] cautioned that athletes with menstrual disturbances also have other risk factors like greater training loads, lower calcium intake, and differences in soft tissue composition. While this may be the case among athletes, in Basic Combat Training the training load is similar for all recruits and all recruits have access to the same calcium sources in the dining facility. Nonetheless, in a Basic Combat Training study in 1993, calcium intake of recruits was only 73 percent of the military recommended daily allowance [4]. One study found that amenorrheic women had lower bone mineral density even after controlling for calcium intake [99].

In the present investigation, a prior pregnancy was associated with higher injury risk but past studies in basic training have demonstrated mixed results regarding this association [27,43]; no other studies could be found in the civilian literature on the effects of prior pregnancy on injuries in physically active women. The American College of Obstetricians and Gynecologists noted that "many of the physiological and morphological changes of pregnancy persist 4-6 weeks postpartum" and recommended that "prepregnancy exercise routines may be resumed gradually as soon as it is medically safe" [103]. One possible mechanism to explain a possible association between prior pregnancy and injury may be the effects of pregnancy on joint laxity. During pregnancy, relaxin acts in concert with estrogen to increase ligament laxity by reducing the density of collagen fiber bundles [104]. This could increase the likelihood of ligament injury due to excessive joint flexibility $[105,106]$. However, the highest levels of relaxin occur in the first trimester and relaxin levels decline for the rest of pregnancy with no antepartum surge, although it continues to be released by the corpus luteum throughout pregnancy [104]. Joint relaxation in the symphysis pubis increases during pregnancy but returns to baseline 3 to 5 months post delivery [106]. Thus, it seems unlikely that joint laxity accounts for the relationship between prior pregnancy and injury, although some longer-term effects of pregnancy cannot be altogether ruled out [106]. It also seemed possible that prior pregnancy covaried with age, because those who had been pregnant were slightly older than those who had not (ages $=20.1 \pm 2.1$ versus $23.2 \pm 5.2, \mathrm{p}<0.01)$. However, stratifying pregnancy history by age showed little difference in injury incidence during MP training among the age groups for those who had and had not been previously pregnant.

\section{Conclusions}

The present investigation was the first to identify injury rates and identify specific factors increasing injury risk during MP training. At least one training injury was experienced by $34.2 \%$ of the men and $66.7 \%$ of the women. Recruits were at higher injury risk if they reported that they were older, had smoked in the past, or had performed less frequent exercise or sports prior to MP training. Men were at higher injury risk if they reported a prior injury and women were at higher risk if they reported missing at least six menstrual cycles in the last year or had previously been pregnant.

\section{Abbreviations}

MP: Military Police; OSUT: One-Station Unit Training; AFHSC: Armed Forces Health Surveillance Center; ICD-9: International Classification of Diseases, Revision 9, Clinical Modification; Cll: Comprehensive injury index; BMI: Body mass index; SPSS: Statistical Package for the Social Sciences; 95\%Cl: 95\% Confidence interval; HR: Hazard ratio; AWOL: Absent without leave.

\section{Competing interests}

The authors declare that they have no competing interests.

\section{Authors' contributions}

JJK participated in the design of the study, assisted with data collection, assisted with compiling the data, performed the statistical analysis, interpreted the data, and drafted the manuscript. BG, JC, DT, RS collected and complied data, assisted with the interpretation of the data, and helped draft the manuscript. BHJ participated in the design of the study, assisted in the interpretation of the data, and helped draft the manuscript. All authors read and approved the final manuscript.

\section{Acknowledgements}

We would like to thank individuals who assisted with the organization of this investigation including Ms Martha Collins, LTC Dean Kucera, MSG James Clayton, LTC Glasscock, MAJ Adam Smith, SSG Jamal Williams, Ms Shelley Delamarter, Ms Portia Ellis and Mr Brian Raymond. This research was supported in part by an appointment to the Knowledge Preservation Program at the U.S. Army Public Health Command (USAPHC) administered by the Oak Ridge Institute for Science and Education through an interagency 
agreement between the U.S. Department of Energy and USAPHC. The views, opinions, and/or findings contained in this report are those of the authors and should not be construed as official Department of the Army position, policy, or decision, unless so designated by other official documentation. Approved for public release; distribution is unlimited.

\section{Author details}

${ }^{1}$ US Army Institute of Public Health, Portfolio of Epidemiology and Disease Surveillance, ATTN: MCHB-IP-DI, 1570 Stark Road, Aberdeen Proving Ground, MD 21010, USA. ${ }^{2}$ Medical University of South Carolina, Department of Obstetrics and Gynecology, Charleston, SC, USA. ${ }^{3}$ AIDS Resource Center of Wisconsin, Milwaukee, WI 53203, USA.

Received: 10 October 2012 Accepted: 10 January 2013

Published: 17 January 2013

\section{References}

1. Knapik JJ, Hauret KG SC, Marin R, Jones BH: Association between ambulatory physical activity and injuries in United States Army Basic Training. J Phys Act Health 2011, 8:496-502.

2. Jones BH, Bovee MW, Harris JM, Cowan DN: Intrinsic risk factors for exercise-related injuries among male and female Army trainees. Am J Sports Med 1993, 21:705-710.

3. Knapik JJ, Sharp MA, Canham-Chervak M, Hauret K, Patton JF, Jones $\mathrm{BH}$ : Risk factors for training-related injuries among men and women in Basic Combat Training. Med Sci Sports Exerc 2001, 33:946-954.

4. Westphal KA, Friedl KE, Sharp MA, King N, Kramer TR, Reynolds KL, Marchitelli LJ: Health, performance and nutritional status of U.S. Army women during basic combat training. Natick, MA: U.S. Army Research Institute of Environmental Medicine, Technical Report No. T96-2; 1995.

5. Knapik JJ, Swedler D, Grier T, Hauret KG, Bullock S, Williams K, Darakjy S, Lester $\mathrm{M}$, Tobler $\mathrm{S}$, Jones $\mathrm{BH}$ : Injury reduction effectiveness of selecting running shoes based on plantar shape. J Strength Cond Res 2009, 23:685-697.

6. Knapik JJ, Trone D, Swedler DI, Villasenor A, Schmied E, Bullock S, Jones $\mathrm{BH}$ : Injury reduction effectiveness of assigning running shoes based on foot shape in Marine Corps basic training. Aberdeen Proving Ground MD: US Army Center for Health Promotion and Preventive Medicine, No. 12-MA-05SBA-08B; 2009.

7. Jones BH, Cowan DN, Tomlinson JP, Robinson JR, Polly DW, Frykman PN: Epidemiology of injuries associated with physical training among young men in the Army. Med Sci Sports Exerc 1993, 25:197-203.

8. Knapik JJ, Darakjy S, Scott S, Hauret KG, Canada S, Marin R, Palkoska F, VanCamp S, Piskator E, Rieger W, et al: Evaluation of two Army fitness programs: the TRADOC Standardized Physical Training Program for Basic Combat Training and the Fitness Assessment Program. Aberdeen Proving Ground, MD: US Army Center for Health Promotion and Preventive Medicine, Technical Report No. 12-HF-5772B-04; 2004.

9. Haddon W: Energy damage and ten countermeasure strategies. J Trauma 1973, 13:321-331.

10. Knapik JJ, Burse RL, Vogel JA: Height, weight, percent body fat and indices of adiposity for young men and women entering the U.S. Army. Aviat Space Environ Med 1983, 54:223-231.

11. Open Epidemiological Calculator. http://www.openepi.com/Menu/ OpenEpiMenu.htm], Assessed 12 August 2012

12. Knapik JJ, Brosch LC, Venuto M, Swedler DI, Bullock SH, Gaines LS, Murphy $\mathrm{RJ}$, Tchandja J, Jones BH: Effect on injuries of assigning shoes based on foot shape in Air Force Basic Training. Am J Prev Med 2010, 38:S197-S211.

13. National Institute of Health (NIH): Clinical guidelines on the identification, evaluation, and treatment of overweight and obesity in adults. Bethesda MD: NIH Publication No. 98-4083; 1998.

14. American College of Sports Medicine: The recommended quantity and quality of exercise for developing and maintaining cardiorespiratory and muscular fitness, and flexibility in healthy adults. Med Sci Sports Exerc 1998, 30:975-991.

15. Hosmer DW, Lemeshow S: Applied Logistic Regression. New York: John Wiley \& Sons; 1989.

16. Knapik JJ, Hauret KG, Arnold S, Canham-Chervak M, Mansfield AJ, Hoedebecke EL, McMillian D: Injury and fitness outcomes during implementation of Physical Readiness Training. Int J Sports Med 2003, 24:372-381.

17. Knapik JJ, Darakjy S, Scott SJ, Hauret KG, Canada S, Marin R, Rieger W, Jones $\mathrm{BH}$ : Evaluation of a standardized physical training program for Basic Combat Training. J Strength Cond Res 2005, 19:246-253.

18. Heir T, Eide G: Injury proneness in infantry conscripts undergoing a physical training programme: smokeless tobacco use, higher age, and low levels of physical fitness are risk factors. Scand J Med Sci Sports 1997 7:304-311.

19. Knapik JJ, Spiess A, Swedler D, Grier T, Darakjy S, Amoroso P, Jones BH: Injury risk factors in parachuting and acceptability of the parachute ankle brace. Aviat Space Environ Med 2008, 79:689-694.

20. Schmidt MD, Sulski SI, Amoroso PJ: Effectiveness of an external ankle brace in reducing parachute-related ankle injuries. Med Sci Sports Exerc 2004, 36:S312

21. Knapik JJ, Grier T, Spiess A, Swedler DI, Hauret KG, Graham B, Yoder J, Jones $\mathrm{BH}$ : Injury rates and injury risk factors among Federal Bureau of Investigation new agent trainees. BMC Public Health 2011, 11:920. doi:910.1186/1471-2458-1111-1920.

22. Conboy IM, Rando TA: Aging, stem cells and tissue regeneration. Cell Cycle 2005, 4:407-410.

23. Chodzko-Zajko WJ, Proctor DN, Sing MAF, Minson CT, Nigg CR, Salem GJ, Skinner JS: Exercise and physical activity for older adults. Med Sci Sports Exerc 2009, 41:1510-1530.

24. Knapik JJ, Jones BH, Vogel JA, Banderet LE, Bahrke MS, O'Connor JS: Influence of age and body mass index on measures of physical fitness in U.S. Army Soldiers. J Aging Phys Act 1996, 4:234-250.

25. Jones BH, Bovee MW, Knapik JJ: Associations among body composition, physical fitness, and injuries in men and women Army trainees. In Body Composition and Physical Performance. Edited by Marriott BM, Grumstrup-Scott J. Washington, D.C: National Academy Press; 1992:141-173.

26. Knapik JJ, Cuthie J, Canham M, Hewitson W, Laurin MJ, Nee MA, Hoedebecke E, Hauret K, Carroll D, Jones BH: Injury incidence, injury risk factors, and physical fitness of U.S. Army basic trainees at Ft Jackson SC, 1997. Aberdeen Proving Ground, MD: U.S. Army Center for Health Promotion and Preventive Medicine, Epidemiological Consultation Report No. 29-HE-7513-98; 1998.

27. Knapik JJ, Sharp MA, Canham ML, Hauret K, Cuthie J, Hewitson W, Hoedebecke E, Laurin MJ, Polyak C, Carroll D, et al: Injury incidence and injury risk factors among US Army Basic Trainees at Ft Jackson, SC (including fitness training unit personnel, discharges, and newstarts). Aberdeen Proving Ground MD: US Army Center for Health Promotion and Preventive Medicine, Epidemiological Consultation Report No. 29-HE-8370-99; 1999

28. Shaffer RA, Brodine SK, Almeida SA, Williams KM, Ronaghy S: Use of simple measures of physical activity to predict stress fractures in young men undergoing a rigorous physical training program. Am J Epidemiol 1999 149:236-242.

29. Rauh MJ, Macera CA, Trone DW, Shaffer RA, Brodine SK: Epidemiology of stress fracture and lower-extremity overuse injuries in female recruits. Med Sci Sports Exerc 2006, 38:1571-1577.

30. Jones BH, Shaffer RA, Snedecor MR: Injuries treated in outpatient clinics: surveys and research data. Mil Med 1999, 164(Suppl):6-1-6-89.

31. Knapik JJ, Brosch LC, Venuto M, Swedler DI, Bullock SH, Gaines LS, Murphy RJ, Canada SE, Hoedebecke EL, Tobler SK, et al: Injury reduction effectiveness of prescribing running shoes based on foot shape in Air Force Basic Military Training. Aberdeen Proving Ground MD: Army Center for Health Promotion and Preventive Medicine, Technical Report No. 12-MA-05SBA-08A; 2008.

32. Forde MS, Punnett L, Wegman DH: Prevalence of musculoskeletal symptoms in union ironworkers. J Occup Env Hyg 2005, 2:203-212

33. Knapik JJ, McCollam R, Canham-Chervak M, Arnold S, DuVernoy TS, Hoedebecke EL: A second investigation of injuries among officers attending the US Army War College during Academic Year 2000. Aberdeen Proving Ground, MD: US Army Center for Health Promotion and Preventive Medicine, EPICON Report No. 29-HE-2682-00; 2000

34. Knapik JJ, Spiess A, Darakjy S, Grier T, Manning F, Livingstone E, Swedler D, Amoroso $\mathrm{P}$, Jones $\mathrm{BH}$ : Risk factors for parachute injuries and comments about the parachute ankle brace among airborne students. Aberdeen Proving Ground MD: US Army Center for Health Promotion and Preventive Medicine, Technical Report No. 12-MA01Q2-08B; 2008. 
35. Knowles SB, Marshall SW, Bowling JM, Loomis D, Millikan R, Yang J, Weaver $\mathrm{NL}$, Kalsbeek W, Miller FO: A prospective study of injury incidence among North Carolina high school athletes. Am J Epidemiol 2006, 164:1209-1221.

36. Macera CA, Pate RR, Powell KE, Jackson KL, Kendrick JS, Craven TE: Predicting lower-extremity injuries among habitual runners. Arch Int Med 1989, 149:2565-2568.

37. Marti B, Vader JP, Minder CE, Abelin T: On the epidemiology of running injuries. The 1984 Bern Grand-Prix study. Am J Sports Med 1988, 16:285-294

38. Orchard JW: Intrinsic and extrinsic risk factors for muscle strains in Australian football. Am J Sports Med 2001, 29:300-303.

39. Schneider GA, Bigelow C, Amoroso PJ: Evaluating risk of re-injury among 1,214 Army Airborne soldiers using a stratified survival model. Am J Prev Med 2000, 18(Suppl3):156-163.

40. VanMechelen W, Twisk J, Molendijk A, Blom B, Snel J, Kemper HC: Subjectrelated risk factors for sports injuries: a 1-yr prospective study in young adults. Med Sci Sports Exerc 1996, 28:1171-1179.

41. Voaklander DC, Saunders LD, Quinney HA: Personal risk factors for injury in recreational and old-timer ice hockey. Sports Med Training Rehabil 1998, 8:239-250.

42. Walter SD, Hart LE, McIntosh JM, Sutton JR: The Ontario cohort study of running-related injuries. Arch Int Med 1989, 149:2561-2564.

43. Knapik JJ, Swedler D, Grier T, Hauret KG, Bullock S, Williams K, Darakjy S, Lester M, Tobler S, Clemmons N, et al: Injury reduction effectiveness of prescribing running shoes based on foot shape in Basic Combat Training. Aberdeen Proving Ground MD: US Army Center for Health Promotion and Preventive Medicine, Technical Report No. 12-MA-05SB-08; 2008.

44. Altarac M, Gardner JW, Popovich RM, Potter R, Knapik JJ, Jones BH: Cigarette smoking and exercise-related injuries among young men and women. Am J Prev Med 2000, 18(Suppl 3S):96-102.

45. Lappe JM, Stegman MR, Recker RR: The impact of lifestyle factors on stress fractures in female Army recruits. Osteoporosis Int 2001, 12:35-42.

46. Valimaki W, Alfthan E, Lehmuskallio E, Loyttyniemi E, Sah T, Suominen H, Valimakii MJ: Risk factors for clinical stress fractures in male military recruits: a prospective cohort study. Bone 2005, 37:267-273.

47. Reynolds KL, Heckel HA, Witt CE, Martin JW, Pollard JA, Knapik JJ, Jones BH: Cigarette smoking, physical fitness, and injuries in infantry soldiers. Am J Prev Med 1994, 10:145-150.

48. Cady LD, Bischoff DP, O'Connell ER, Thomas PC, Allen JH: Strength and fitness and subsequent back injuries in firefighters. J Occ Med 1979, 21:269-272.

49. Chau N, Bourgkard E, Bhattacherjee A, Ravaud JF, Choquet M, Mur JM: Associations of job, living conditions and lifestyle with occupational injury in working population: a population-based study. Int Arch Occup Environ Health 2008, 81:379-389.

50. MCSweeney KP, Congleton JJ, Kerk CJ, Jenkins OE, Craig BN: Correlation of recorded injury and illness data with smoking, exercise, and absolute aerobic capacity. Int J Ind Ergonomics 1999, 24:193-200.

51. Jones JK, Triplett RG: The relationship of cigarette smoking to impaired intraoral wound healing. J Oral Maxillofac Surg 1992, 50:237-239.

52. Mosely LH, Finseth F, Goody M: Nicotine and its effect on wound healing. Plast Reconstr Surg 1978, 61:570-575.

53. Reus WF, Robson MC, Zachary L, Heggers JP: Acute effects of tobacco smoking in the cutaneous micro-circulation. Br J Plast Surg 1984, 37:213-215.

54. Riefkohl R, Wolfe JA, Cox EB, McCarthy KS: Association between cutaneous occlusive vascular disease, cigarette smoking, and skin slough after rhytidectomy. Plast Reconstr Surg 1986, 77:592-595.

55. Siana JE, Rex S, Gottrup F: The effect of cigarette smoking on wound healing. Scand J Plast Reconstr Surg 1989, 23:207-209.

56. Goodson WH, Hunt TK: Wound healing in well-controlled diabetic men. Surg Forum 1984, 35:614-616.

57. Jorgensen LN, Kallehave F, Christensen E, Siana JE, Gottrup F: Less collagen production in smokers. Surgery 1998, 123:450-455.

58. Knuutinen A, Kokkonen N, Risteli J, Vahakangas K, Kallioinen M, Salo T, Oikarinen A: Smoking affects collagen synthesis and extracellular matrix turnover in human skin. Br J Dermatol 2002, 146:588-594.

59. Castillo RC, Bosse MJ, MacKenzie EJ, Patterson BM: Impact of smoking of fracture healing and risk of complications in limb-threatening open tibia fractures. J Orthop Trauma 2005, 19:151-157.
60. Riebel GD, Boden SD, Whitesides TE, Hutton WC: The effects of nicotine on incorporation of cancellous bone graft in an animal model. Spine 1995, 20:2198-2202

61. Raikin SM, Landsman JC, Alexander VA, Froimson MI, Plaxton NA: Effect of nicotine on the rate and strength of long bone fracture healing. Clin Orthop 1998, 353:231-237.

62. Silcox DH, Daftari T, Boden SD, Schimandle JH, Hutton WC, Whitesides TE: The effect of nicotine on spinal fusion. Spine 1995, 14:1549-1553.

63. Chen F, Osterman L, Mahony K: Smoking and bony union after ulnashorting osteotomy. Am J Orthop 2001, 30:486-489.

64. Karim A, Pandit H, Murray J, Wandless F, Thomas NP: Smoking and reconstruction of the anterior cruciate ligament. J Bone Jt Surg (Br) 2006, 88:1027-1031

65. Gill CS, Sandell LJ, El-Zawawy HB, Wright RW: Effects of cigarette smoking on early medial collateral ligament healing in a mouse model. $J$ Orth Res 2006, 24:2141-2149.

66. Wong LS, Green HM, Feugate JE, Yadav M, Nothnagel EA, MartinsGreen M: Effects of "second hand" smoke on structure and function of fibroblasts, cells that are critical for tissue repair and remodeling. BMC Cell Biol 2004, 5:13.

67. Carnevali S, Nakamura Y, Mio T, Liu X, Takigawa K, Romberger DJ, Spurzem JR, Rennard SI: Cigarette smoke extract inhibits fibroblast-mediated collagen gel contraction. Am J Physiol Cell Physiol 1998, 274:L591-L598.

68. Nakamura Y, Romberger DJ, Tate L, Ertl RF, Kawamoto M, Adachi Y, Sisson JH, Spurzem JB, Rennard SI: Cigarette smoke inhibits fibroblast proliferation and chemotaxis. Am J Respir Crit Care Med 1995, 151:1497-1503.

69. Raveendran M, Senthil D, Utama B, Shen Y, Dudley D, Wang J, Zhang Y, Wang XL: Cigarette suppresses the expression of P4Halpha and vascular collagen production. Biochem Biophys Res Commun 2004, 323:592-598.

70. Schaffer M, Barbul A: Lymphocyte function in wound healing and following injury. Br J Surg 1998, 85:444-460

71. Barbul A, Regan MC: Immune involvement in wound healing. Otolaryngol Clin North Am 1995, 28:955-968.

72. DiPietro LA: Wound healing: the role of macrophages and other immune cells. Shock 1995, 4:233-240.

73. Park JE, Barbul A: Understanding the role of immune regulation in wound healing. Am J Surg 2004, 187(Suppl 1):11S-16S.

74. Sopori ML, Kozak W: Immunomodulatory effects of cigarette smoke. J Neuroimmunol 1998, 83:148-156.

75. Chen H, Cowan MJ, Hasday JD, Vogel SN, Medvedev AE: Tobacco smoke inhibits expression of proinflammatory cytokines and activation of IL-1Rassociated kinase, p38, and NF-kappa-B in aveolar macrophages stimulated with TLR2 and TLR4 angonists. J Immunol 2007, 179:6097-6106.

76. McCrea KA, Ensor JE, Nall K, Bleeker ER, Hasday JD: Altered cytokine regulation in the lungs of cigarette smokers. Am J Respir Crit Care Med 1994, 150:696-703.

77. Tollerud DJ, Clarke JW, Brown LM, Neuland CY, Mann DL, Pankiw-Trost LK, Blattner WA, Hoover RN: Association of cigarette smoking with decreased numbers of circulating natural killer cells. Am Rev Resp Dis 1989, 139:194-198.

78. Hersey P, Prendergast D, Edwards A: Effects of cigarette smoking on the immune system. Med J Aust 1983, 2:425-429.

79. Miller LG, Goldstein G, Murphy M, Ginns LC: Reversible alterations in immunoregulatory T Cells in smoking. Chest 1982, 82:526-529.

80. Yarnell JWG, Sweetnam PM, Rogers S, Elwood PC, Bainton D, Baker IA, Esatham R, Etherington MD: Some long term effects of smoking from the Caerphilly and Speedwell Collaborative Surveys. J Clin Pathol 1987, 40:909-913.

81. Friedman GD, Siegelaub AB, Seltzer CC, Feldman R, Collen MF: Smoking habits and the leukocyte count. Arch Environ Health 1973, 26:137-143.

82. Hughes DA, Haslam PL, Townsend PJ, Turner-Warwick M: Numerical and functional alterations in circulatory lymphocytes in cigarette smokers. Clin Exp Immunol 1985, 61:459-466.

83. Nobel RC, Penny BB: Comparison of leukocyte count and function in smoking and nonsmoking men. Infect Immun 1975, 12:550-555.

84. Lando HA, Haddock CK, Klesges RC, Talcott GW, Jensen J: Smokeless tobacco use in a population of young adults. Addict Behav 1999, 24:431-447.

85. Difranza JR, Winters TH, Goldberg RJ, Cirillo L, Biliouris T: The relationship of smoking to motor vehicle accidents and traffic violations. NY State J Med 1986, 86:464-467. 
86. Eiser JR, Sutton SR: Smoking, seat belts, and beliefs about health. Addict Behav 1979, 4:331-338.

87. Chiolero A, Wietlisbach V, Ruffieux C, Paccaud F, Cornuz J: Clustering of risk behaviors with cigarette consumption: a population-based survey. Prev Med 2006, 42:348-353.

88. Gardner LI, Dziados JE, Jones BH, Brundage JF, Harris JM, Sullivan R, Gill P: Prevention of lower extremity stress fractures: a controlled trial of a shock absorbent insole. Am J Public Health 1988, 78:1563-1567.

89. Kohrt WM, Bloomfield SA, Little KD, Nelson ME, Yingling VR: Physical activity and bone health. Position stand of the American College of Sports Medicine. Med Sci Sports Exerc 2004, 36:1985-1996

90. Garber CE, Blissmer B, Deschenes MR, Franklin BA, Lamonte MJ, Lee IM, Nieman DC, Swain DP: Quantity and quality of exercise for developing and maintaining cardiorespiratory, musculoskeletal, and neuromuscular fitness in apparently healthy adults: guidance for prescribing exercise. Med Sci Sports Exerc 2011, 43(7):1334-1359.

91. Knapik JJ, Darakjy S, Hauret KG, Canada S, Scott S, Rieger W, Marin R, Jones BH: Increasing the physical fitness of low fit recruits before Basic Combat Training: an evaluation of fitness, injuries and training outcomes. Mil Med 2006, 171:45-54

92. Knapik JJ, Trone DW, Swedler DI, Villasenor A, Bullock SH, Schmied E, Brockelman T, Han P, Jones BH: Injury reduction effectiveness of assigning running shoes based on plantar shape in Marine Corps basic training. Am J Sports Med 2010, 38:1759-1767.

93. Rauh MJ, Koepsell TD, Rivara FP, Margherita AJ, Rice SG: Epidemiology of musculoskeletal injuries among high school cross-country runners. Am J Epidemiol 2006, 163:151-159.

94. Silder A, Heiderscheit BC, Thelen DG, Enright T, Tuite MJ: MR observation of long-term musculoskeletal remodeling following a hamstring strain injury. Skeletal Radiol 2008, 37:1101-1109.

95. Silder $A$, Thelen DG, Heiderscheit BC: Effects of prior hanstring injury of strength, flexibility and running mechanics. Clin Biomech 2010, 25(7):681-686.

96. Shaffer RA, Rauh MJ, Brodine SK, Trone DW, Macera CA: Predictors of stress fractures in young female recruits. Am J Sports Med 2006, 34:108-115.

97. Lloyd T, Triantafyllou SJ, Baker ER, Houts PS, Whiteside JA, Kalenak A, Stumpf PG: Women athletes with menstrual irregularity have increased musculoskeletal injuries. Med Sci Sports Exerc 1986, 18:374-379.

98. Bennell KL, Malcom SA, Thomas SA, Reid SJ, Brukner PD, Ebeling PR, Ward JD: Risk factors for stress fractures in track and field athletes. A twelvemonth prospective study. Am J Sports Med 1996, 24:810-818.

99. Davis MC, Hall ML, Jacobs HS: Bone mineral loss in young women with amenorrhoea. Br Med J 1990, 301:790-793.

100. Beckvid-Henriksson G, Schnell C, Linden-Hirschberg A: Women endurance runners with menstrual dysfunction have prolonged interruption of training due to injury. Gynecol Obstet Invest 2000, 49:41-46.

101. Feingold D, Hame SL: Female athletic triad and stress fractures. Orthop Clin North Am 2006, 37:575-583.

102. Bennell K, Matheson G, Meeuwisse W, Brukner P: Risk factors for stress fractures. Sports Med 1999, 28:91-122.

103. American College of Obstetricians and Gynecologists: Exercise during pregnancy and the postpartum period. Obstet Gynecol 2002, 99:171-173.

104. Sherwood OD: Relaxin's physiological roles and other diverse actions. Endocr Rev 2004, 25:205-234.

105. Calguneri M, Bird HA, Wright V: Changes in joint laxity occurring during pregnancy. Ann Rheum Dis 1982, 41:126-128.

106. Abramson D, Roberts SM, Wilson PD: Relaxation of the pelvic joints in pregnancy. Surg Gynecol Obstet 1934, 58:595-613.

doi:10.1186/1471-2474-14-32

Cite this article as: Knapik et al:: A prospective investigation of injury incidence and injury risk factors among army recruits in military police training. BMC Musculoskeletal Disorders 2013 14:32.

\section{Submit your next manuscript to BioMed Central and take full advantage of:}

- Convenient online submission

- Thorough peer review

- No space constraints or color figure charges

- Immediate publication on acceptance

- Inclusion in PubMed, CAS, Scopus and Google Scholar

- Research which is freely available for redistribution

Submit your manuscript at www.biomedcentral.com/submit
C Biomed Central 